\title{
Learning Using Animated Video Media to Improve Student Learning Outcomes
}

\author{
Universitas Perjuangan Tasikmalaya \\ piopurwanti17@gmail.com
}

Pio Purwanti, Yus Darusman, Riza Fatimah Zahrah

\section{Article History}

accepted 05/11/2020

approved 10/11/2020

published 01/02/2021

\begin{abstract}
This research is based on the problems that occurred at SDN Margaluyu. Through observations that have been made at SDN Margaluyu that the learning process is less attractive without the use of media. The scores of students in social studies subjects are still much below the KKM with KKM IPS scores of 75. In connection with these problems, the researchers conducted research with the aim of improving learning outcomes in social studies using animated video media. The population of this study was grade IV students, amounting to 26 students. The sampling technique used was random sampling of 10 students. The method used is classroom action research. The data collection technique used multiple choice test sheets. Obtained from the results of the analysis in cycle l, the number of students who met the KKM was 6 students or $60 \%$, while the results of the analysis in cycle II had an increase in all students completing the KKM or $100 \%$. So it can be concluded that learning using animated video media can improve student learning outcomes in social studies subjects on economic activity material in class IV SDN Margaluyu.
\end{abstract}

Keywords: animated video media, learning outcomes

\begin{abstract}
Abstrak
Penelitian ini berdasarkan permasalahan yang terjadi di SDN Margaluyu . Melalui observasi yang sudah dilakukan di SDN Margaluyu bahwa dalam proses pembelajaran yang kurang menarik tanpa penggunaan media. Nilai siswa pada mata pelajaran IPS masih banyak dibawah KKM dengan nilai KKM IPS 75. Berkaitan dengan masalah tersebut, maka peneliti melakukan penelitian dengan tujuan untuk memperbaiki hasil belajar pada mata pelajaran IPS Menggunakan media video animasi. Populasi dari penelitian ini siswa kelas IV yang berjumlah 26 siswa. Teknik sampling yang digunakan yaitu random sampling sebanyak 10 siswa. Metode yang digunakan yaitu penelitian tindakan kelas. Teknik pengumpulan data menggunakan lembar tes pilihan ganda. Diperoleh dari hasil analisis siklus I jumlah siswa yang untas memenuhi KKM sebanyak 6 siswa atau $60 \%$ sedangkan hasil analisis siklus II mengalami peningkatan semua siswa tuntas memenuhi KKM atau 100\%. Maka dapat disimpulkan bahwa pembelajaran dengan menggunakan media video animasi dapat meningkatkan hasil belajar siswa pada mata pelajaran IPS materi kegiatan ekonomi di kelas IV SDN Margaluyu.
\end{abstract}

Kata kunci: media video animasi, hasil belajar

Social, Humanities, and Education Studies (SHEs): Conference Series https://jurnal.uns.ac.id/shes

p-ISSN 2620-9284

e-ISSN 2620-9292 


\section{PENDAHULUAN}

Permendiknas No. 22 tahun 2006 sebagai acuan pelaksanaan pembelajaran di indonesia menjelaskan bahwa,

IImu Pengetahuan Sosial (IPS) merupakan salah satu mata pelajaran yang diberikan dari mulai SD/MI/SDLBsampai SMP/MTS/SMPLB. IPS mengkaji seperangkat peristiwa, fakta, konsep, dan generalisasi yang berkaitan dengan isu sosial. Pada jenjang SD/MI memuat materi geografi, sejarah, sosiologi, dan ekonomi. Melalui mata pelajaran IPS, Indonesia yang demokratis, dan bertanggung jawab serta warga dunia yang cinta damai.

Tujuan dari Pembelajaran IPS yang tercantum pada Permendiknas No.24 tahun 2006 yaitu agar siswa memiliki kemampuan dari pembelajaran IPS sebagai berikut: 1) mengenal konsep-konsep yang berkaitan dengan kehidupan masyarakat dan lingkungannya; 2) memiliki kemampuan dasar untuk berfikir logis dan kritis, rasa ingin tahu, inkuiri, memecahkan masalah, dan keterampilan dalam kehidupan sosial; 3) memiliki komitmen dan kesadaran terhadap nilai-nilai sosial dan kemanusiaan; 4) memiliki kemampuan berkomunikasi, bekerja sama dan berkompetisi dalam masyarakat yang majemuk, ditingkat lokal, nasional, dan global (Depdiknas, 2007). Dalam mencapai tujuan IPS tersebut terdapat permasalahan dalam strategi pembelajaran IPS. Adanya pemahaman yang salah bahwa pelajaran IPS adalah pelajaran hafalan. Sehingga dikelas lebih banyak aktivitas guru ketimbang siswanya. Guru lebih sering memberikan materi dibanding siswa mencari sendiri. Sarana pembelajaran juga merupakan permasalahan lainya karena guru masih banyak yang tidak menggunakan media pembelajaran atau alat peraga dalam proses pembelajaran (Depdiknas 2007).

Berdasarkan hasil Pengamatan yang dilakukan di SDN Margaluyu, peneliti menemukan permasalahan yang berkaitan dengan IPS, salah satunya yaitu dalam kegiatan belajar mengajar disekolah SD pada pembelajaran IPS, biasanya pada pembelajaran IPS suasana kelas kurang kondusif, banyak peserta didik yang konsentrasinya menurun, ada yang ngantuk, atau bahkan siswa yang duduk di kursi paling belakang berbicara dengan temannya. Berdasarkan hasil wawancara dengan bapak Eman Suherman selaku wali kelas IV di SDN Margaluyu mengatakan bahwa hasil belajar siswa kelas IV tergolong rendah dilihat dari nilai UAS semester 1 tahun ajaran 2019/2020. Dari jumlah 26 siswa hanya 11 siswa atau 42,3\% siswa yang memenuhi nilai KKM, dengan nilai KKM IPS mencapai angka 75. Sedangkan 15 siswa atau $57,7 \%$ siswa lain nilai nya kurang dari KKM. Maka dari 10 sampel yang diambil oleh peneliti terdapat 6 siswa atau $60 \%$ yang tidak memenuhi KKM dan 4 siswa atau $40 \%$ siswa yang memenuhi nilai KKM. Salah satu penyebab rendahnya hasil belajar IPS yang dicapai siswa yaitu kurangnya pemahaman terhadap materi yang diajarkan oleh guru. Sebagai seorang guru hendaknya menciptakan suatu proses pembelajaran yang tidak membosankan, harus kreatif dan inovatif untuk meningkatkan pemahaman siswa. Akan tetapi berdasarkan wawancara dengan Kepala Sekolah, salah satu permasalahan yang ada disekolah ini adalah kurangnya penggunaan media terutama media video, media video belum pernah digunakan oleh guru dalam proses pembelajaran.

Berdasarkan permasalahan di atas dari hasil observasi, perlu adanya pembenahan dalam menyampaikan materi, salah satunya menyampaikan materi 
dengan menggunakan media. Media dalam pembelajaran merupakan alat/benda yang digunakan untuk mempermudah proses pembelajaran. Gagne"dan Briggs dalam (Rahmayanti, 2016: 5) Media pembelajaran meliputi alat yang secara fisik digunakan untuk menyampaikan isi materi pengajaran, yang terdiri dari antara lain buku, tape recorder, kaset, video, kamera, video recorder, film, slide (gambar bingkai), foto, gambar, grafik, televisi, dan komputer. Dengan kata lain media adalah komponen sumber belajar yang dapat merangsang siswa untuk belajar. Sementara itu menurut Asosiasi Pendidikan Nasional (National Education Assosiation/ NEA) (Sadiman et al, 2010: 7) menyatakan Media adalah bentuk-bentuk komunikasi baik tercentak maupun audiovisual serta peralatan-peralatannya untuk membantuk proses pembelajaran.Dengan perkembangan zaman serta kemajuan teknologi saat ini salah satu media yang tepat untuk digunakan adalah video. Munir (Fadhli, 2015: 25) menyatakan video adalah teknologi yang bisa menangkap, merekam, mengolah, dan merekontruksi urutan gambar-gambar diam dengan menyajikan adegan demi adegan dalam gerak secara elektronik. Menurut Ayuningsih (2017: 45) menyatakan bahwa media video animasi merupakan sebuah tampilan yang menggabungkan antara media teks, grafik dan suara dalam suatu aktivitas penggerakan secara elektronik dan dikemas menarik untuk menarik perhatian siswa.

Adapun tujuan dari penelitian ini antara lain (1) Mendeskripsikan perencanaan pembelajaran dengan menggunakan media video animasi pada pelajaran IPS di kelas IV SDN Margaluyu, (2)Mendeskripsikan pembelajaran dengan penggunaan media video animasi pada pelajaran IPS di kelas IV SDN Margaluyu, (3) Mendeskripsikan peningkatkan hasil belajar siswa pada pelajaran IPS di kelas IV SDN Margaluyu dengan penggunaan media video animasi.

\section{METODE}

Metode penelitian ini menggunakan metode Penelitien Tindakan Kelas (PTK). Dimaksudkan agar memaksimalkan hasil penelitian. Memilih PTK ini karena dapat melakukan penelitian secara langsung terhadap siswa. Penelitian terhadap siswa dilihat dari segi aspek interaksinya dalam proses pembelajaran serta secara reflektif dapat menganalisis dan mensintesis terhadap apa yang telah dilakuan dikelas. Sehingga peneliti dapat memperbaiki hal-hal yang perlu diperbaiki. dalam peneliitian tindakan kelas ini dapat digambarkan sebagai berikut:

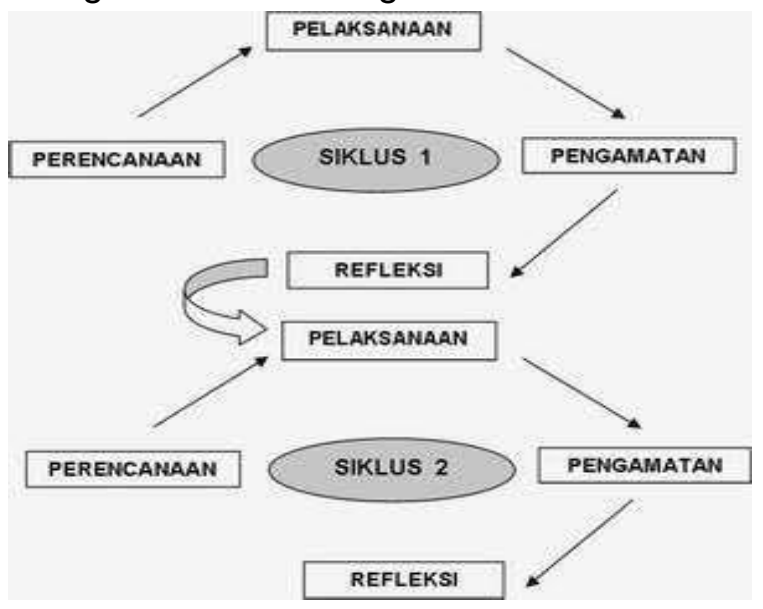

Gambar 1. Siklus PTK Model Kemmis dan Mc Tagart 
a. Sasaran Penelitian

Populasi sasaran dari penelitian ini adalah seluruh siswa siswi kelas IV di SDN Margaluyu Kecamatan Manonjaya Kabupaten Tasikmalaya yang berjumlah 26 siswa. Teknik sampel yang digunakan dalam penelitian ini adalah Sample Random Sampling. Menurut Sugiyono (2016: 120) Sample Random Sampling adalah sampel sederhana karena pengambilan anggota sampel dari populasi dilakukan secara acak tanpa memperhatikan strata yang ada dalam populasi itu yang dianggap homogen. dikarenakan penelitian ini dilakukan dalam situasi negara Indonesia di landa bencana virus copid-19, yang tidak memungkinkan seluruh siswa kelas IV mengikuti proses penelitian maka peneliti hanya menggunakan 10 siswa yang terdiri dari 6 siswa laki-laki dan 4 siswa perempuan kelas IV SDN Margaluyu.

b. Teknik Pengumpulan Data

Teknik pengumpulan data yang digunakan untuk memperoleh data-data empiris yang dapat digunakan untuk mencapai tujuan penelitian. Pada penelitian ini terdapat tiga teknik pengumpulan data yaitu teknik observasi, teknik tes, dan teknik dokumentasi. (1.)Teknik observasi menurut Nasution (Sugiyono, 2016: 310) menyatakan observasi adalah dasar semua ilmu pengetahuan. Para ilmuan hanya dapat bekerja berdasarkan data, yaitu mengenai fakta mengenai dunia kenyataan dan diperoleh melalui observasi. Dengan observasi peneliti lebih mudah memahami konteks data dalam keseluruhan. Teknik observasi yang dilakukan oleh peneliti adalah observasi kuantitatif, melalui lembar observasi yang dinilai oleh rekan sejawat atau guru kelas. (2.)Teknik Tes, Teknik tes merupakan usaha pemahaman siswa dengan menggunakan alat-alat yang bersifat mengukur. Menurut Peters dan Shertzer (Setiawati dan Chudari, 2015: 42) Tes merupakan prosedur sistematis untuk mengetahui hasil pemahaman siswa melalui skala angka.Teknik tes yang digunakan oleh peneliti adalah tes tulis dengan bentuk soal PG (Pilihan Ganda) dan tes tanya jawab.(3.)Teknik Dokumentasi, Dokumentasi merupakan sekumpulan berkas untuk mencari suatu data berupa catatan, buku, surat kabar, majalah dan sebagainya. Menurut Sugiyono (2016: 329) menyatakan bahwa "Dokumen merupakan catatan peristiwa yang sudah berlalu". Dalam penelitian ini beberapa data siswa yang dibutuhkan sepertai absensi kelas, nilai-nilai hasil ulangan harian dan lain lain.

c. Teknik Analisis Data

Karena datanya kuantitatif maka teknik analisis data menggunakan metode statistik yang sudah tersedia. Pengolahan data dan menganalisis data dilakukan melalui langkah-langkah sebagai berikut: (1.) Reduksi data (Data Reduction). Reduksi data dari data kuantitatif berarti menggunakan analisis data statistik deskriptif. Statistik deskriptif merupakan statistik yang digunakan untuk menganalisis data dengancara mendeskripsikan atau menggambarkan data yang telah terkumpul seadanya tanpa bermaksud membuat kesimpulan sendiri melainkan berlaku untuk umum (Sugiyono, 2016:210). Adapun penghitunganya dilakukan dengan cara persentase. Menurut Sudijono (Yuniarti, et al, 2015: 4) Dengan rumus:

$$
\begin{aligned}
& \mathrm{P}=\frac{f}{N} \times 100 \% \\
& \text { Keterangan : } \\
& \mathrm{P}=\text { Angka persentase } \\
& \mathrm{f}=\text { Frekuensi yang sedang dicari persentasinya }
\end{aligned}
$$


$\boldsymbol{N}=$ Number of clases (jumlah frekuensi/ banyaknya individu).

(2.) Penyajian Data (Data Display) Setelah data di reduksi, maka langkah selanjutnya mendisplay data. Dalam mendisplay data kuantitatif menurut Sugiyona, (2016: 341) menyatakan "Dalam penelitian kuantitatif penyajian datanya dalam bentuk tabel atau grafik dan sejenisnya, dengan data tersebut, maka data terorganisasikan, tersusun dalam pola hubungan sehingga akan semakin mudah difahami". Dengan kata lain penyajian data ini digunakan untuk mempermudah peneliti dalam pemahaman pembanca mengenai hasil dari penelitian ini. Dan peneliti akan menggunakan grafik sebagai penyajian data hasil akhirnya. (3.) Menurut Miles and Huberman (Sugiyono, 2016: 345) menyatakan kesimpulan awal yang dikemukakan masih bersifat sementara, dan akan berubah apabila tidak disertakan dengan bukti-bukti yang kuat yang mendukung pada saat pengumpulan data. Dengan demikian kesimpulan dalam penelitian mungkin dapat menjawab rumusan masalah yang dirumuskan dari awal mungkin tidak. Maka dari itu penelitian ini memiliki kriteria ketuntasan yaitu $\geq 85 \%$. Apabila hasil akhir ketuntasan siswa kurang dari $85 \%$ maka harus kembali melakukan penelitian ulang atau siklus selanjutnya, sampai mencapai kriteria ketuntasan yang telah di tentukan yaitu $\geq 85 \%$.

\section{a. Hasil Observasi dan Penilaian RPP}

\section{HASIL DAN PEMBAHASAN}

Berdasarkan hasil penilaian observer maka diperoleh rekapitulasi jumlah skor aktivitas guru dan siswa serta komponen RPP siklus I dan siklus II dapat dilihat pada tabel 1 berikut ini:

Tabel 1. Rekapitulasi Hasil Observasi dan Penilaian RPP

\begin{tabular}{ccc}
\hline \multirow{2}{*}{ Penilaian } & \multicolumn{2}{c}{ Jumlah Skor } \\
& siklus I & Siklus II \\
\hline Observasi Guru & 60 & 70 \\
Observasi & 30 & 37 \\
Siswa & 89 & 92 \\
RPP & 8 \\
\hline
\end{tabular}

Berdasarkan tabel 1 diketahui bahwa adanya peningkatan hasil observasi aktivitas guru dan siswa serta penilaian komponen RPP setelah dilakukanya tindakan. Pada tabel 1 menunjukan hasil jumlah skor observasi guru pada siklus I adalah 60 dan siklus II 72. Sedangkan jumlah skor observasi siswa pada siklus I adalah 30 dan siklus II 37. Serta jumlah skor penilaian komponen RPP siklus I 89 dan siklus II 92. Ketiga penilaian ini berdasarkan data tersebut dapat digambarkan dengan gambar 2 di bawah ini: 


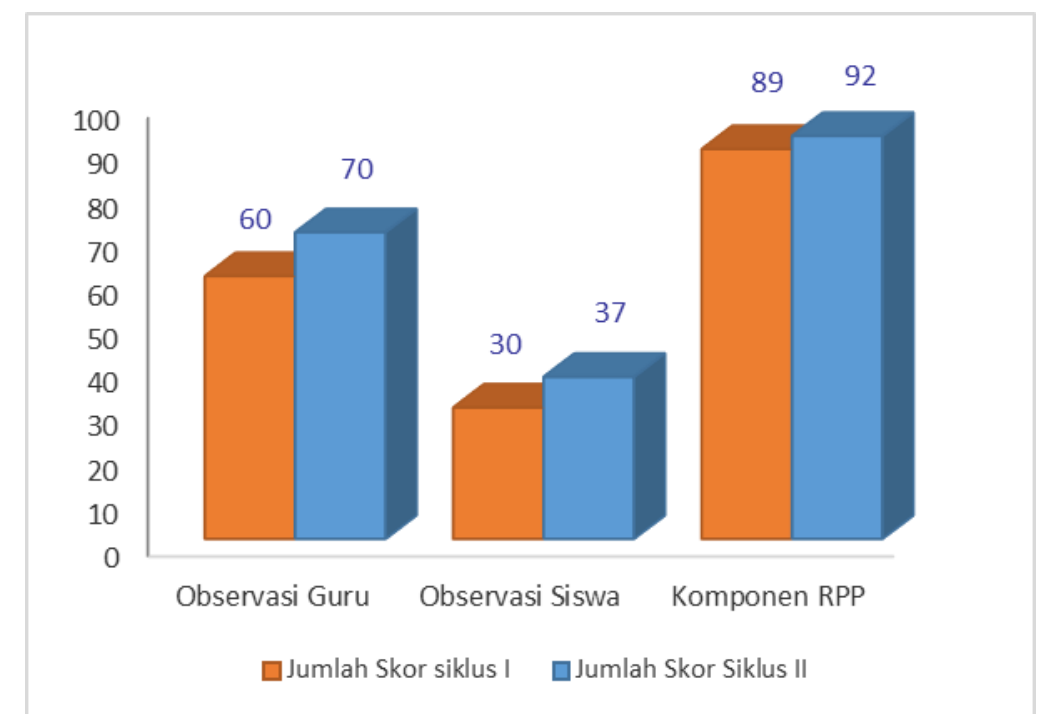

Gambar 2. Rekapitulasi Hasil Observasi dan penilaia RPP

1. Hasil Belajar Siswa

a. Hasil Ketuntasan Siswa Pra Siklus

Tabel 2. Hasil Belajar Siswa Pra Siklus

\begin{tabular}{cccccc}
\hline \multirow{2}{*}{ No } & Nama Siswa & \multirow{2}{*}{ Kkm } & Nilai & \multicolumn{2}{c}{ Keterangan } \\
& & & & Tuntas & Tidak Tuntas \\
\hline 1. & AA & 75 & 60 & & V \\
2. & DAN & 75 & 60 & & V \\
3. & DPJ & 75 & 70 & & V \\
4. & FA & 75 & 60 & & \\
5. & FRP & 75 & 80 & V & \\
6. & KA & 75 & 80 & V & \\
7. & MA & 75 & 70 & & V \\
8. & MFR & 75 & 70 & & \\
9. & PFM & 75 & 80 & V & \\
10. & RSP & 75 & 80 & V & \\
\multicolumn{7}{c}{ Rata-Rata } & & 70 & & 6 \\
\hline
\end{tabular}

Berdasarkan Tabel 2 dapat dijelaskan bahwa siswa kelas IV masih rendah dalam pembelajarana IPS terutama materi kegiatan ekonomi. Yakni dapat dilihat dari data nilai siswa, hanya 4 siswa (40\%) yang mendapatkan nilai mencapai KKM yaitu $\geq 75$ dan 6 siswa (60\%) yang mendapatkan nilai dibawah KKM.

b. Hasil Ketuntasan Siswa Siklus I

Tabel 3. Hasil Belajar Siswa Siklus I

\begin{tabular}{cccccc}
\hline \multirow{2}{*}{ No } & Nama Siswa & Kkm & Nilai & \multicolumn{2}{c}{ Keterangan } \\
& & & & Tuntas & Tidak Tuntas \\
\hline 1. & AA & 75 & 70 & & V \\
2. & DAN & 75 & 80 & V & \\
\hline
\end{tabular}




\begin{tabular}{cccccc}
\hline 3. & DPJ & 75 & 70 & & $\mathrm{~V}$ \\
4. & FA & 75 & 70 & & $\mathrm{~V}$ \\
5. & FRP & 75 & 80 & $\mathrm{~V}$ & \\
6. & KA & 75 & 90 & $\mathrm{~V}$ & \\
7. & MA & 75 & 80 & $\mathrm{~V}$ & \\
8. & MFR & 75 & 80 & $\mathrm{~V}$ & \\
9. & PFM & 75 & 90 & $\mathrm{~V}$ & \\
10. & RSP & 75 & 80 & $\mathrm{~V}$ & \\
& Rata-Rata & & 79 & & 3 \\
\hline
\end{tabular}

Berdasarkan tabel 3 menunjukan bahwa, dapat diketahui hasil siklus I siswa yang tuntas dengan KKM $\geq 75$ sebanyak 7 siswa atau $70 \%$ dari jumlah 10 siswa yang menjadi sampel kelas IV SDN Margaluyu Kecamatan Manonjaya Kabupaten Tasikmalaya dan siswa yang belum tuntas sebanyak 3 siswa atau $30 \%$.

c. Hasil Ketuntasan Siswa Siklus II

Tabel 4. Hasil Belajar Siswa Siklus II

\begin{tabular}{|c|c|c|c|c|}
\hline \multirow{2}{*}{ No } & \multirow{2}{*}{ Nama Siswa } & \multirow{2}{*}{ Kkm } & \multirow{2}{*}{ Nilai } & Keterangan \\
\hline & & & & Tuntas Tidak Tuntas \\
\hline 1. & AA & 75 & 80 & V \\
\hline 2. & DAN & 75 & 80 & V \\
\hline 3. & DPJ & 75 & 80 & V \\
\hline 4. & FA & 75 & 90 & V \\
\hline 5. & FRP & 75 & 100 & V \\
\hline 6. & $\mathrm{KA}$ & 75 & 100 & V \\
\hline 7. & MA & 75 & 90 & V \\
\hline 8. & MFR & 75 & 100 & V \\
\hline 9. & PFM & 75 & 100 & V \\
\hline 10. & RSP & 75 & 90 & V \\
\hline & Rata-Rata & & 90 & \\
\hline & Jumlah & & & 10 \\
\hline
\end{tabular}

Berdasarkan tabel 4 menunjukan bahwa, dapat diketahui hasil siklus II siswa yang tuntas dalam KKM $\geq 75$ sebanyak 10 siswa atau 100\% dari jumlah 10 siswa yang menjadi sampel kelas IV SDN Margaluyu Kecamatan Manonjaya Kabupaten Tasikmalaya dan tidak ada siswa yang tidak tuntas.

d. Rekapitulasi hasil belajar siswa

Berdasarkan hasil analisis pengumpulan data maka diperoleh kesimpulan data hasil belajar. Rekapitulasi hasil belajar siswa dapat dilihat pada tabel 4.8 berikut ini:

Tabel 5. Rekapitulasi Hasil Belajar Per Siklus

\begin{tabular}{ccccc}
\hline Siklus & Rata-rata & Keterangan & Jumlah Siswa & Persentase \\
\hline \multirow{2}{*}{ Pra siklus } & 70 & Tuntas & 4 & $40 \%$ \\
\multirow{2}{*}{ Siklus I } & \multirow{2}{*}{79} & Tidak tuntas & 6 & $60 \%$ \\
& & Tuntas & 7 & $70 \%$ \\
Siklus II & \multirow{2}{*}{91} & Tidak tuntas & 3 & $30 \%$ \\
& & Tuntas & 10 & $100 \%$ \\
& & Tidak tuntas & - & $0 \%$
\end{tabular}

Berdasarkan Tabel 5 diketahui bahwa adanya peningkatan hasil belajar siswa setelah dilakukan tindakan. Pada tabel 5 menunjukan hasil pra siklus terdapat 4 siswa (40\%) yang tuntas dan 6 siswa (60\%) yang tidak tuntas KKM dengan 
perolehan rata-rata 70 . Berdasarkan hasil belajar siswa tersebut ketuntasan siswa termasuk kategori rendah maka peneliti melanjutkan ke siklus I dengan waktu yang berbeda. Hasil belaja siawa pada siklus I terdapat 7 siswa (70\%) yang tuntas dan 3 siswa $(30 \%)$ yang tidak tuntas KKM dengan memperoleh rata-rata 79 . Persentase ketuntasan hasil belajar siswa dari pra siklus ke siklus I yaitu sebesar $30 \%$. berdasarkan hasil belajar siswa tersebut belum memenuhi kriteria ketuntasn yaitu $\geq$ $85 \%$ maka kemudian peneliti melanjutkan ke siklus II dengan materi yang sama dan waktu yang berbeda. Hasil belajar siawa pada siklus II terdapat 10 siswa (100\%) yang tuntas dari KKM dengan memperoleh rata-rata 91. Persentase ketuntasan hasil belajar siswa dari siklus I ke siklus II yaitu sebesar 30\%. berdasarkan hasil belajar siswa tersebut diketahui bahwa pada siklus II angka persentase ketuntasan hasil belajar siswa memperoleh $100 \%$ maka penelitian dinyatakan dihentikan karena sudah memenuhi kriteria ketuntasn yaitu $\geq 85 \%$. Berdasarkan data tersebut maka dapat diketahui bahwa pelaksanaan penelitian Tindakan Kelas (PTK) dengan menggunakan media video animasi berhasil meningkatkan hasil belajar siswa pada pembelajaran IPS materi kegiatan ekonomi. yang dapat digambarkan dengan gambar 3 dibawah ini:

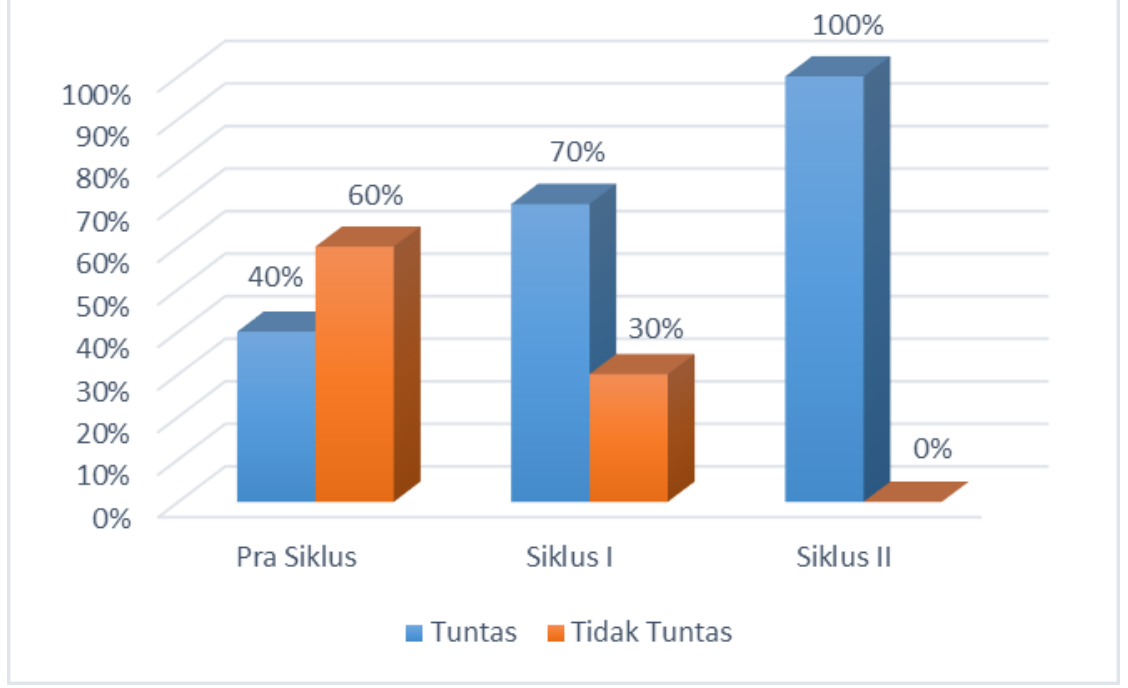

Gambar 3. Rekapitulasi Hasil Belajar Per Siklus

\section{Pembahasan}

Berdasarkan hasil penelitian yang telah dilaksanakan pembahasan mata pelajaran IPS tentang kegiatan ekonomi dengan menggunakan media video animasi pada siswa kelas IV SDN Margaluyu. Selama proses pembelajaran siswa sangat antusias melihat layar monitor dinyalakan, terlihat dari pra siklus ke siklus I dari persentase ada peningkatan sebanyak $30 \%$ dari 10 siswa ada 3 siswa yang belum tuntas, padahal jumlah siswa lebih sedikit ketimbang di prasiklus tapi masih ada beberapa siswa yang kelihatanya sangat memperhatikan pada saat guru menerangkan, namun ternyata nilainya masih kurang KKM. Sehingga peneliti lebih meningkatkan perhatian siswa di siklus II, seperti diawal pembelajaran menyanyi bersama sambil melihat video klip lagu dan penambahan reward di akhir pembelajaran. Di siklus II semua anak tuntas melebihi nilai KKM. Ketuntasan dari penilaian tes hasil belajar siswa pada siklus I menunjukkan nilai rata-rata kelas yaitu 79 dengan siswa yang tuntas yaitu sebanyak 7 siswa dari 10 jumlah sampel siswa kelas IV sehingga presentase yang diperoleh sebesar $70 \%$, karena siswa kurang aktif dalam pembelajaran sehingga nilai yang diperoleh siswa masih ada yang belum mencapai KKM yaitu 75. Pada perbaikan siklus II siswa mulai terbiasa menggunakan pembelajaran dengan menggunakan media video animasi sehingga hasil belajar siswa meningkat. Terlihat dari kenaikan nilai rata-rata kelas pada siklus II yaitu 91 yang 
sudah mencapai KKM dengan siswa yang tuntas yaitu 10 siswa dari 10 jumlah sampel siswa kelas IV SDN Margaluyu. Presentase dari penilaian tes hasil belajar pada siklus II memperoleh $100 \%$.

Pembahasan di atas sesuai dengan pendapat Johari, et al, (2014: 10) yang ada pada bab II menunjukkan bahwa pembelajaran dengan menggunakan media video animasi dapat menarik perhatian siswa dan memberikan pemahaman yang lebih cepat sehingga dapat meningkatkan hasil belajar siswa mencapai kriteria ketuntasan minimal dalam mata pelajaran IPS tentang kegiatan ekonomi dan siswa aktif dalam proses pembelajaran. Dari hasil penelitian yang dilakukan dapat diketahui bahwa penelitian telah mengalami keberhasilan karena hasil ketuntasan siswa sudah mencapai $\geq 85 \%$. Maka dari itu hipotesis peneliti diterima. Yang artinya, jika pembelajaran IPS pada materi kegiatan ekonomi menggunakan media video animasi dengan tepat, maka dapat meningkatkan hasil belajar siswa kelas IV SDN Margaluyu.

\section{SIMPULAN}

Berdasarkan hasil penelitian di SDN Margaluyu dan berawal dari masalahmasalah yang ada, maka di simpulkan bahwa pembelajaran dengan menggunakan media video animasi dapat meningkatkan hasil belajar siswa pada mata pelajaran IPS materi Kegiatan Ekonomi terlihat dari hasil tes tulis pilihan ganda yang meningkat jumlah ketuntasan siswanya dari Pra siklus sebanyak 4 sisa atau $40 \%$, ke siklus I menjadi 7 siswa atau $70 \%$ dan ke siklus II 10 siswa atau samua sisa yang menjadi sampel penelitian dengan persentase hasil belajar siswa sebangak $100 \%$, oleh karena itu, Penelitian Tindakan Kelas (PTK) ini dinyatakan dihentikan karena telah memenuhi syarat indikator keberhasilan yaitu $\geq 85 \%$. Peningkatan hasil belajar ini tidak lepas dari bantuan perencanaan serta pelaksanaan observasi guru dan siswa dengan hasil yang baik bahkan termasuk kategori sangat baik.

\section{DAFTAR PUSTAKA}

Ayuningsih, K. (2017). Pengaruh Video Animasi Ternadap Hasil Belajarkognitif Pada Mata Pelajaran IPS Materi Menghargai Jasa Pahlawan Dikelas V SDN Sidokumpulsidoarjo. Journal Of Information And Computer Technology.

Pemerintah Indonesia. (2006). Permendiknas Nomor 22 tahun2006 tentang IImu Pengetahuan Sosial (IPS). Sekertariat Negara: Jakarta.

Pemerintah Indonesia. (2007). Depdiknas Nomor 24 tahun 2007 tentang tujuan pembelajaran IPS. Sekertariat Negara: Jakarta.

Fadhli. (2015). Pengembangan media pembelajaran berbasis video kelas IV Sekolah dasar.Jurnal dimensi pendidikan dan pembelajaran, Vol. 3. No. 1. P 24-33. 1 Januari 2015. Indonesia: Universitas Muhammadiyah Ponorogo.

Johari et al. (2014). Penerapan Media Video Animasi Pada Materi Memvakum Dan Mengisi Refrigen Terhadap Hasil Belajar Siswa. Vol. 1 No. 1. 2014. Indonesia: Journal of mechanical engineering education.

Rahmayanti, A. (2016). Keefektifan Media Video Terhadap Minat Dan Hasil Belajar IPA Kelas V SD Negeri Kepandaian 03 Kecamatan Dukuhturi Kabupaten Tegal. Skripsi. UNNES: Semarang. (Tidak dipublikasikan).

Setiawati dan Cundari, I. (2007). Bimbingan dan Konseling. Bandung: UPI PRESS.

Sugiyono. (2016). Metode Penelitian Pendidikan (Pendekatan Kuantitatif, Kualitatif, dan $R \& D)$. Bandung: ALFABETA, cv.

Yuniarti, et Al. (2015). Peningkatan Hasil Belajar Dengan Menggunakan Media Video Dalam Pembelajaran IPA Di Sekolah Dasar. Jurnal pendidikan sekolah dasar.oktober 2015. Indonesia: Universitas pontianak 